\title{
Fourier Transform Infrared Spectroscopy Typing an Enterococcus sp.
}

\author{
Mohammad I. Abu Taha1 ${ }^{*}$, Hatem K. Eideh², Sameeh M. Saed ${ }^{3}$, Hazem Jaber ${ }^{4}$ \\ ${ }^{1}$ Physics Department, Al-Quds University, Jerusalem, Palestinian Territories \\ ${ }^{2}$ Medical Laboratory Sciences Department, Al-Quds University, Jerusalem, Palestinian Territories \\ ${ }^{3}$ Iskander Khoury Secondary School, Bethelehem, Palestinian Territories \\ ${ }^{4}$ Medical Lab, Al-Maqased Hospital, Jerusalem, Palestinian Territories \\ Email: *mabutaha@science.alquds.edu
}

Received 21 July 2014; revised 18 August 2014; accepted 12 September 2014

Copyright (C) 2014 by authors and Scientific Research Publishing Inc.

This work is licensed under the Creative Commons Attribution International License (CC BY).

http://creativecommons.org/licenses/by/4.0/

c) (i) Open Access

\begin{abstract}
Enterococcus species are one of the leading causes of nosocomial infections, which are difficult to treat specially with the rise of its Vancomycin resistant. Studies of Enterococcus isolates are essential for epidemiological investigation. Typing Enterococci is often based on the traditional phenotypic as well as genotypic methods. In this study Fourier-transform infrared (FTIR) spectroscopy is used as a novel phenotypic approach to the typing of Enterococci. FTIR spectroscopy results compared to antibiotic susceptibility testing and PCR amplification of Vancomycin gene results; the analysis showed that, 6 isolates were positive for Van gene (4 of VanA, 1 of VanB and 1 VanA plus VanB). Three of VanA and VanA plus VanB were resistant to all antibiotic tested (Ampicillin, Teicoplamin and Vancomycin) and VanB was found to be sensitive. FTIR spectroscopy (first derivatives) divided the isolates into 8 groups. 3 groups of VanA (4 isolates), one of VanB (one isolate), one of VanA plus VanB (one isolate) and the other 13 Enterococcus isolates were divided into 3 clusters. The study demonstrated that FTIR spectroscopy has good discriminative capacity and high reproducibility as compared to other techniques.
\end{abstract}

\section{Keywords}

Enterococci, Antibiotic Susceptibility Testing, FTIR Spectroscopy, PCR, VRE Typing

\section{Introduction}

Enterococci is an opportunistic human pathogens, the two most important species of this group are E. faecalis

"Corresponding author. 
and E. faecium, which are considered as the leading causes of nosocomial infections. It also causes: endocarditis, septicemia, intra-abdominal, pelvic and urinary tract infections [1]. These infections are often difficult to treat due to the increased antibiotic resistance associated with this organism [2]-[4]. The recent increase of vancomycin-resistant, vre enterococci strains in clinical isolates is especially a cause of serious concern, because the types of glycopeptide antibiotics often remains the last treatment available in life-threatening infections [5]. This situation is further complicated by the fact that Enterococci have developed a number of mechanisms for the transfer of resistance genes [6]. In general, this has resulted in an increased need for rapid and accurate identification of Enterococci as a means of effectively assisting infection control and epidemiological investigations.

For most clinical microbiological laboratories, the primary method of identifying Enterococcus strains relies on the traditional phenotypic characterization. However, it is a challenging procedure that can take several days to accomplish because of the phenotypic and biochemical similarities between many Enterococci [7]. Molecular genetic techniques have been successfully used to identify Enterococci at the species level [8]-[11], but it is difficult to adapt them for use in routine laboratories due to their high costs and the requirement for highly skilled personnel.

An extensive approach for investigation of bacterial cells of different bacterial species and strains has been undertaken by Neumann and his co-worker [12]-[15]. They have shown that FT-IR absorption spectra are highly specific fingerprints of microbial cell.

Attempts to apply Infrared (IR) Spectroscopy technology to biology began as early as the 1910s, when the use of IR spectroscopy for the analysis of biological samples was first suggested. By the late 1940s, the technique was being successfully explored for the study of biological materials and in fact, IR spectroscopy has become an accepted tool for the characterization of biomolecules [14] [15]. The earlier applications of FT-IR in microorganisms date back to the 1950s [16]-[19]. The use of infrared (IR) spectroscopy as a means of differentiating and characterization of bacteria was extensively reported [20]-[22]. The different studies undertaken by Naumann and co-workers of bacterial cells of different species and strains has shown that FT-IR absorption spectra are highly specific fingerprints of microbial cells. They showed that the FTIR spectra of microorganisms display specifically a complete phonetic and a genetic fingerprint of the cells under study, as all cell components depend on the expression of smaller or larger parts of the genome. This is why the specificity of the technique is very high, allowing highly accurate differentiations of microorganisms at quite different taxonomic levels, even down to the subspecies, strain and/or serogroup/serotype level.

FT-IR spectra of intact microbial cells are highly specific fingerprint-like signature. It is a valuable tool for the identification of biological samples of interest [23], microorganisms and in strains characterization, medical applications, pharmaceutical industry and in drinking water control [24].

In the present work, the Fourier Transform Infrared spectroscopy [FTIRS] was used to type Enterococcus sp. that was isolated from a hospital in an attempt to develop a standardized procedure for the differentiation and characterization of Enterococci.

\section{Materials and Methods}

\subsection{Strains Collection and Growth Conditions}

A total of 19 clinical isolates of Enterococcus sp. were collected from different body sites of various hospital wards. A standard strain of e. faecalis (ATCC-51299) was also inculded. The Enterococci isolates were stocked in proper media and stored at $-70^{\circ} \mathrm{C}$.

\subsection{Antibiotics Susceptibility Testing}

Antibiotic susceptibilities were determined by the disk diffusion method on Mueller-Hinton medium (Difco Laboratories), according to the methods outlined by the Clinical and Laboratory Standards Institute, formerly the National Committee for Clinical Laboratory Standard [25]. The antibiotics used are: ampicillin $10 \mu \mathrm{g}$ teicoplanin $30 \mu \mathrm{g}$ and vancomycin $30 \mu \mathrm{g}$ all from oxoid limited England.

\subsection{Molecular Identification of Vre Resistant Genes by Multiplex PCR}

DNA Extraction

DNA was extracted using rapid lysis method [26]; Bacteria were harvested from blood agar plates, one loopful 
by using a $1 \mu \mathrm{L}$ loop. Cells were re-suspended in $50 \mu \mathrm{L}$ of lysostaphin, $100 \mu \mathrm{L} / \mathrm{mL}$ in water; (Sigma chemical Co. USA). Cells suspension were incubated at $37^{\circ} \mathrm{C}$ for 10 minutes. A $50 \mu \mathrm{L}$ of proteinase $\mathrm{K}$ solution 100 $\mu \mathrm{L} / \mathrm{mL}$, (Sigma, USA) and $150 \mu \mathrm{L}$ buffer 0.1 M Tris buffer (pH 7.5) were added and cell suspensions were incubated for an additional $10 \mathrm{~min}$ at $37^{\circ} \mathrm{C}$, and then placed in a boiling water bath for 5 minutes.

\subsection{Multiplex Pcr}

Multiplex polymerase chain reaction or Multiplex pcr was carried out with $25 \mu \mathrm{L}$ reaction volume, each reaction contained $2.5 \mu \mathrm{L}$ of $10 \mathrm{X}$ buffer, $0.5 \mu \mathrm{L}$ of dNTP (Invitrogen, United Kingdom), $0.2 \mu \mathrm{L}$ of VanA primer 5'-CATG AATAGAATAAAAGTTGCAATA-3', 5'-CCCCTTTAACGCTAATACGATCAA-3', and $0.1 \mu \mathrm{L}$ of VanB primer, 5'-GTGACAAACCGGAGGCGAGGA-3', 5'-CCGCCATCCTCCTGCAAAAAA-3', $0.25 \mu \mathrm{L}$ Taq DNA po- lymerase (Invitrogen; United Kingdom) and 3.0 $\mu \mathrm{L}$. Thermocycling DNA was performed in PTC-150 DNA engine with an initial $5 \mathrm{~min}$. denaturation at $95^{\circ} \mathrm{C}$, followed by 30 cycles of denaturation at $95^{\circ} \mathrm{C}$, for 30 seconds, annealing at $55^{\circ} \mathrm{C}$, for $1 \mathrm{~min}$. and extension at $72^{\circ} \mathrm{C}$, for $1 \mathrm{~min}$, followed by a final extension step at $72^{\circ} \mathrm{C}$, for $5 \mathrm{~min}$.

\subsection{FTIR Spectra of Enterococcus sp.}

The Enterococcus sp. was grown under standardized conditions on blood agar plates. A single isolated colony was carefully removed from previously prepared culture using a sterile $1 \mu \mathrm{L}$ disposable loop and suspended in $200 \mu \mathrm{L}$ sterile physiological saline solution $(0.85 \% \mathrm{NaCl})$. Then $120 \mu \mathrm{L}$ of the suspension was evenly spread over the entire surface of a silicon window $32 \mathrm{~mm}$ dia, and allowed to dry for $30 \mathrm{~min}$ at $39^{\circ} \mathrm{C}$, leaving a transparent film suitable for FTIR absorbance transmission measurements. It is reported that first derivatives of infrared spectra were recorded in fingerprint region $900-700 \mathrm{~cm}^{-1}$ [27]. Spectral comparisons were performed using (Origin pro 7.5 software). Four essential measurements were performed to obtain accurate results and yield highest reproducibility. Firstly, by running FTIR spectroscopy scan in the range $1200-400 \mathrm{~cm}^{-1}$ to check for the presence of the absorbance-transmittance spectrum. Secondly, the time effect of keeping the isolate for certain period of time in saline solution was inspected, this measurement was repeated at nine days time intervals for the radiation range $900-400 \mathrm{~cm}^{-1}$. Thirdly, sources of contamination of the prepared samples were investigated. Fourthly, the silicon window spectrum was compared with its data sheet specification to assign the exact background signal value.

\section{Results and Discussion}

Disc diffusion test was carried out for the three antibiotics and results are summarized in Table 1. Fifteen isolates were found sensitive to vancomycin, and 4 resistant. For ampicillin, 12 were sensitive and 7 are resistant. For teicoplanin, 15 isolates were sensitive, 2 intermediate and 2 resistant. The minimum inhibitory concentration obtained for Enterococcus isolates are shown in Table 1. There were 15 sensitive to vancomycin and 4 were resistant. For teicoplanin there were 15 sensitive and 4 resistant. For ampicillin 12 isolates were found to be sensitive and 7 resistant. Three genotypes were obtained for Enterococcus sp., VanA, VanB, VanA plus B as shown in Table 1.

The FTIR spectra of Enterococci samples were obtained in the range $4000-500 \mathrm{~cm}^{-1}$ which includes the known fingerprint region i.e., $900-700 \mathrm{~cm}^{-1}$. The results were repeated for each sample over different times and the results were highly reproducible over the indicated time period as shown in Figure 1. The resulting 8 different spectra groups were designated as G1-G8. Isolates which showed almost identical absorbance peaks and line shapes were considered similar. All isolates had absorbance peak either 725 or $738 \mathrm{~cm}^{-1}$ and most of the groups had an absorbance peak of $830 \mathrm{~cm}^{-1}$ except in group G2 and group G6 which was absent, they had absorbance peak of about $889 \mathrm{~cm}^{-1}$.

Another absorbance peak about $950 \mathrm{~cm}^{-1}$ in the outer fingerprint region was present in six groups and was absent in G2 and G6 (Table 2 and Table 3). For easier comparison of isolates, first-derivative FTIR spectra plotted to show similarities and differences between isolates.

Five different types with different spectra (different absorbance peaks) were obtained of the genotypes VanA, VanB and VanA plus B, one group of VanB (1 isolate), one of VanA plus B (1 isolate) and 3 of VanA (4 isolates) as shown in Figures 2-4 and Table 2. Interestingly VanB (isolate No. 44404) spectrum was similar but 
Table 1. Results for enterococcal isolates regarding zone diameter, Minimum inhibitory concentration, and genotypes.

\begin{tabular}{|c|c|c|c|c|c|c|c|}
\hline \multirow{2}{*}{ Sample No. } & \multicolumn{3}{|c|}{ Disk diffusion results/zone diameter (mm) } & \multicolumn{3}{|c|}{ Minimum inhibitory concentration $(\mu \mathrm{g} / \mathrm{m} 1)$} & \multirow{2}{*}{ Genotypes } \\
\hline & Ampicillin & Teicoplanin. & Vancomycin & Ampicillin & Teicoplanin. & Vancomycin & \\
\hline E. faecalis ATCC 51299 & 20 & 16 & 15 & $<2.0$ & $<2.0$ & 32 & \\
\hline 48198 & 0 & 10 & 0 & 256 & 256 & 256 & VanA \\
\hline 4898 & 0 & 0 & 0 & 16 & 128 & 256 & VanA \\
\hline 41720 & 8 & 20 & 17 & 32 & 16 & 32 & VanA \\
\hline 44932 & 22 & 18 & 17 & $<2.0$ & $<2.0$ & $<2.0$ & \\
\hline 44404 & 27 & 21 & 19 & $<2.0$ & $<2.0$ & $<2.0$ & VanB \\
\hline 45805 & 22 & 20 & 18 & $<2.0$ & $<2.0$ & $<2.0$ & \\
\hline 43191 & 25 & 19 & 17 & $<2.0$ & $<2.0$ & $<2.0$ & \\
\hline 48278 & 0 & 0 & 0 & 256 & 256 & 256 & $\mathrm{Van} A+B$ \\
\hline 45511 & 0 & 12 & 0 & 256 & 256 & 256 & VanA \\
\hline 44218 & 0 & 20 & 18 & 64 & $<2.0$ & $<2.0$ & \\
\hline 41509 & 24 & 19 & 18 & $<2.0$ & $<2.0$ & $<2.0$ & \\
\hline 47892 & 22 & 17 & 17 & $<2.0$ & $<2.0$ & $<2.0$ & \\
\hline 47808 & 21 & 19 & 17 & $<2.0$ & $<2.0$ & $<2.0$ & \\
\hline 47781 & 22 & 20 & 19 & $<2.0$ & $<2.0$ & $<2.0$ & \\
\hline 45416 & 22 & 19 & 17 & $<2.0$ & $<2.0$ & $<2.0$ & \\
\hline 41838 & 0 & 19 & 20 & 256 & $<2.0$ & $<2.0$ & \\
\hline 45148 & 22 & 18 & 17 & $<2.0$ & $<2.0$ & $<2.0$ & \\
\hline 47891 & 23 & 19 & 17 & $<2.0$ & $<2.0$ & $<2.0$ & \\
\hline 44083 & 28 & 22 & 20 & $<2.0$ & $<2.0$ & $<2.0$ & \\
\hline
\end{tabular}

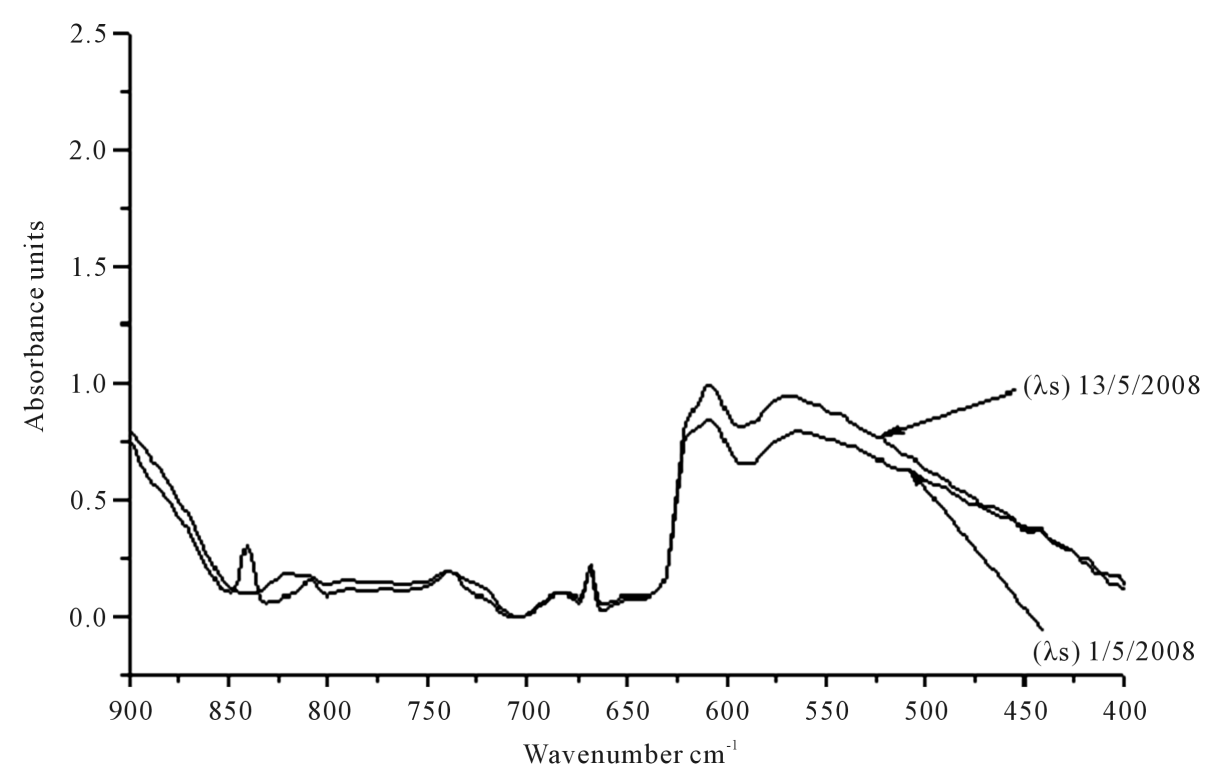

Figure 1. Repetitive FTIR spectra measurements for one isolate over a period of nine days. 
Table 2. Comparison of the absorbance peaks of the genotypes VanA, VanB, VanA plus B and E. faecalis ATCC 51299 VanB.

\begin{tabular}{|c|c|c|c|c|c|c|}
\hline \multirow{2}{*}{$\begin{array}{c}\text { Phenotype } \\
\text { ATCC } 51299 \\
\text { VanB }\end{array}$} & \multirow{2}{*}{$\begin{array}{c}\text { Sample No } \\
\text { ATCC } 51299\end{array}$} & \multicolumn{5}{|c|}{ Absorbance Peaks in the Range (1000 - $\left.500 \mathrm{~cm}^{-1}\right)$} \\
\hline & & 950.11 & 829.56 & 738.06 & 725.72 & 610.87 \\
\hline $\begin{array}{c}\text { Van B } \\
\text { G1 }\end{array}$ & 44404 & 949.94 & 828.92 & 738.01 & 727 & 610.22 \\
\hline VanA & 41720 & - & 889.77 & 738.38 & 618.19 & - \\
\hline G2 & 4898 & - & 889.28 & 738.25 & 611.17 & 541.28 \\
\hline $\begin{array}{c}\text { VanA } \\
\text { G3 }\end{array}$ & 48198 & 950.36 & 829.02 & 738.15 & 610.66 & 508.49 \\
\hline $\begin{array}{c}\text { VanA } \\
\text { G4 }\end{array}$ & 45511 & 950.06 & 830.23 & 724.74 & - & 518.32 \\
\hline $\begin{array}{c}\text { VanA+B } \\
\text { G5 }\end{array}$ & 48278 & 950.66 & 828.69 & 738.15 & 610.68 & - \\
\hline
\end{tabular}

Table 3. Comparison of the absorbance peaks of the non vancomycin resistant Enterococcus isolates.

\begin{tabular}{ccccccc}
\hline Phenotype & Sample No. & \multicolumn{5}{c}{ Absorbance Peaks in the Range $\left(1000-500 \mathrm{~cm}^{-1}\right)$} \\
\hline G6 & 43191 & 545.06 & 611.44 & 738.47 & 892.21 & - \\
G6 & 45148 & 544.57 & 610.42 & 738.55 & 897.94 & - \\
G6 & 47891 & - & 611.03 & 738.30 & 890.80 & - \\
G6 & 44218 & - & 612.08 & 738.43 & 889.16 & 949.57 \\
G7 & 47892 & 511.86 & - & 724.75 & 830.48 & 949.94 \\
G7 & 44932 & 520.05 & - & 724.82 & 830.36 & 949.87 \\
G7 & 44083 & 514.74 & - & 724.85 & 830.36 & 950.33 \\
G7 & 47808 & 509.83 & - & 724.88 & 830.23 & 950.14 \\
G7 & 41838 & 518.42 & - & 724.77 & 830.48 & 950.21 \\
G8 & 45805 & 523.09 & 610.31 & 738.16 & 829.14 & 950.82 \\
G8 & 47781 & 508.54 & 610.72 & 738.23 & 828.09 & 950.62 \\
G8 & 45416 & 531.7 & 610.92 & 738.18 & 828.69 & 950.03 \\
G8 & 41509 & 519.74 & 615.90 & 738.77 & 830.14 & \\
\hline
\end{tabular}

not identical to ATCC which is also VanB genotype as shown in Figure 2. Figure 3 shows three different groups of VanA, isolates numbers: 45511, 41720 and 48198. Figure 4 shows spectra of the isolates numbers: 44404, 45511 and 48278, i.e. comparing the spectra of VanB, VanA, VanA+B groups respectively. The rest of Enterococcus isolates were typed into another three different groups, G6 four isolates, G7 five isolates and G8 four isolates as shown in Figure 5, Figure 6 and Figure 7 respectively.

Enterococcus sp. is considered the second most common bacteria responsible for nosocomial infections with increasing ampicillin and vancomycin resistance [28]. VanA and VanB are among the glycopeptide resistance determinants encountered in clinical settings [29]. In this study we aimed to explore the vancomycin resistant of Enterococcus specimens isolated from a hospital. The isolates were typed using antibiotic susceptibility testing, vancomycin resistant gene and FTIR spectroscopy. Three genotypes of vancomycin resistant were found to be circulating in the hospital which is considered an alarming signal since the genes coding for vancomycin resistance is located on conjugative transposon [30]. It is found that antibiotic susceptibility testing was not discriminative enough compared to FTIR which has proven to be very useful typing technique. The reproducibility 


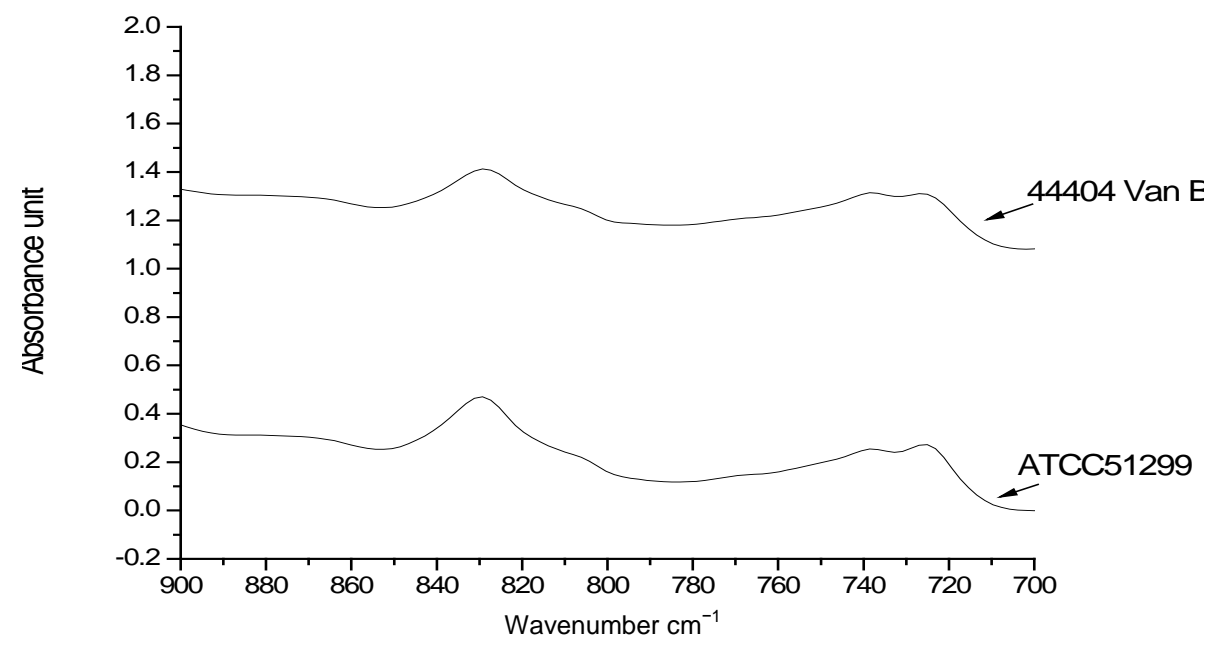

Figure 2. Spectra of ATCC 51299 VanB and VanB isolate number 44404 in the range 900 $700 \mathrm{~cm}^{-1}$.

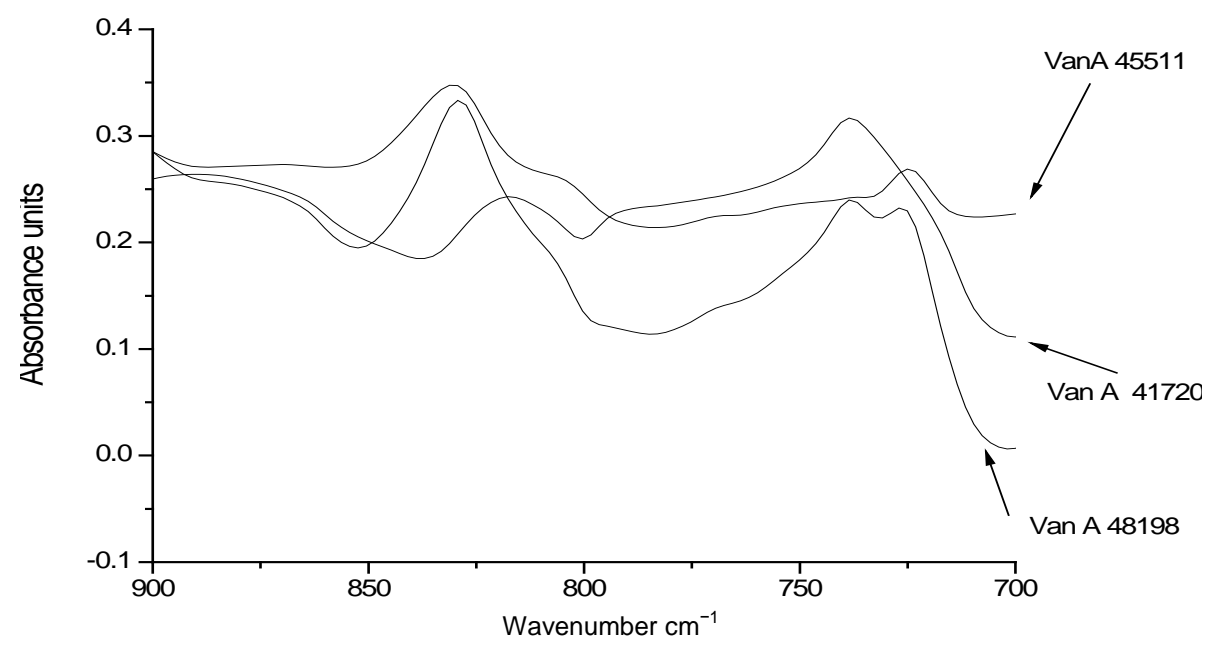

Figure 3. Spectra of VanA type of the samples numbers: 45511, 41720 and 48198 taken in the fingerprint region $900-700 \mathrm{~cm}^{-1}$.

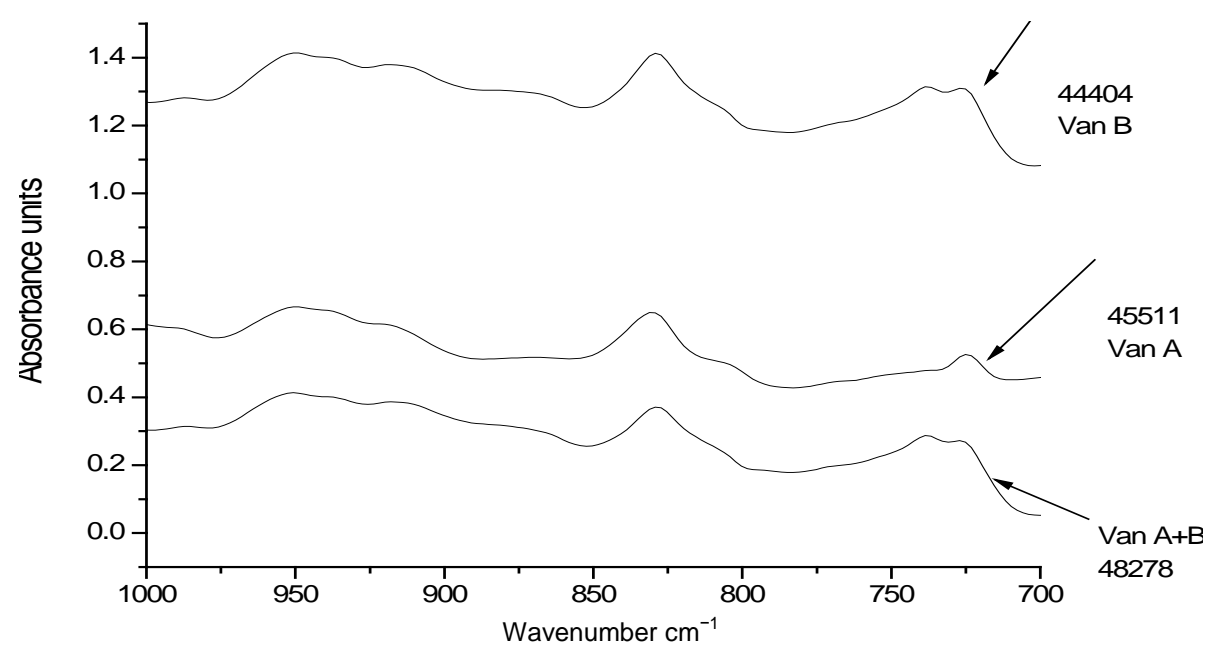

Figure 4. Spectra of VanB, VanA and VanA plus B isolates over the range $1000-700 \mathrm{~cm}^{-1}$. 


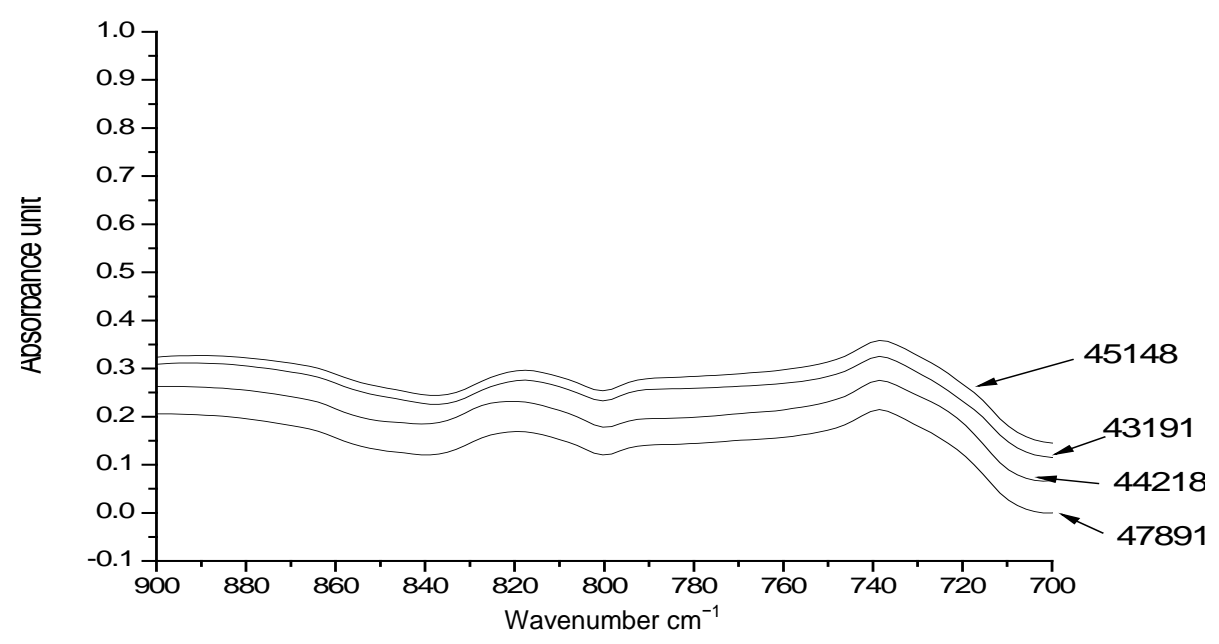

Figure 5. Comparisons between spectra of the group G6 samples in the fingerprint region $900-700 \mathrm{~cm}^{-1}$.

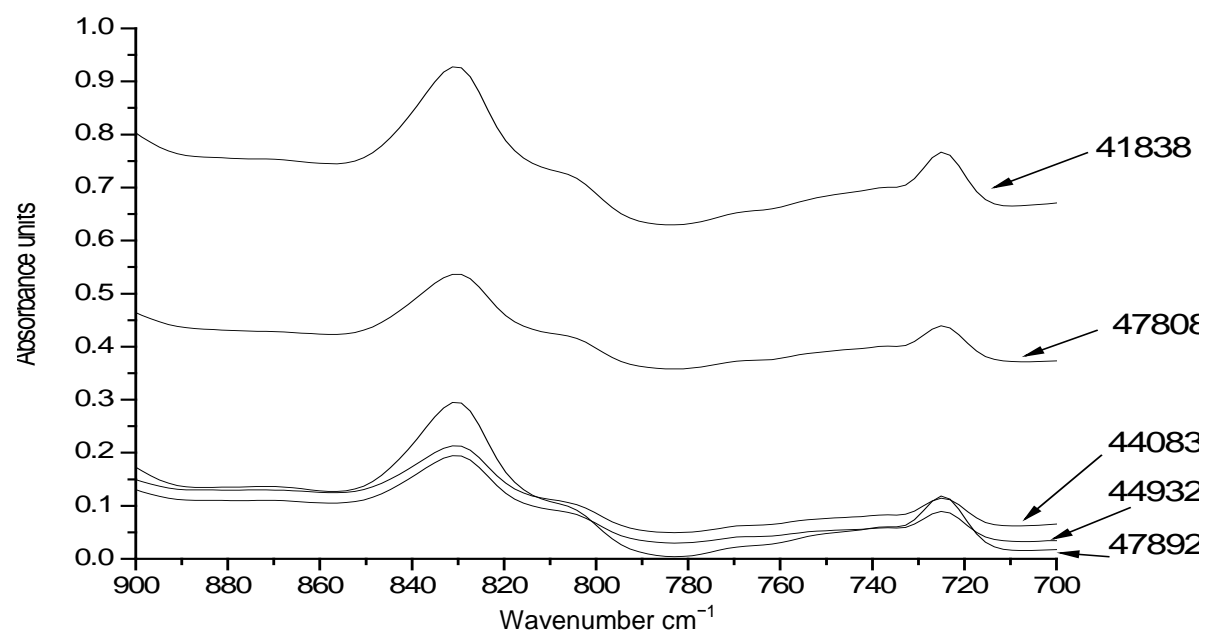

Figure 6. Comparisons between spectra of the group G7 samples in the fingerprint region $900-700 \mathrm{~cm}^{-1}$.

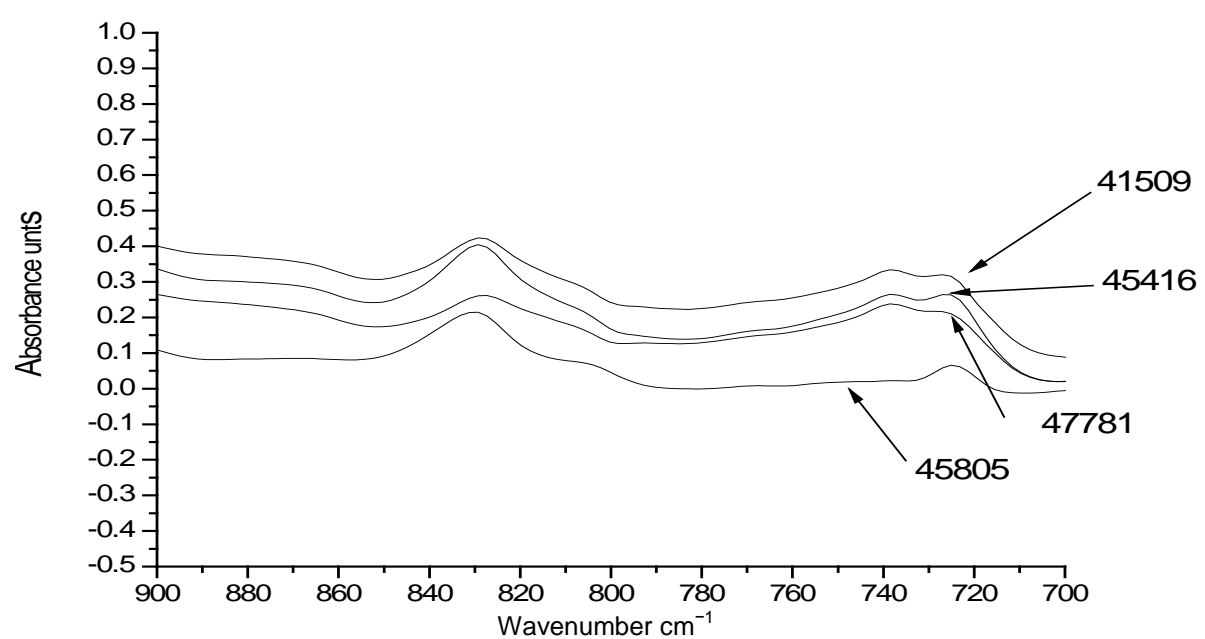

Figure 7. Comparisons between spectra of the group G8 samples in the fingerprint region $900-700 \mathrm{~cm}^{-1}$. 
of FTIR technique was tested by subjecting the same isolates to the test on different separated times. According to FTIR results, the 19 enterococcus isolates were divided into 8 clusters. Predominant absorbance peaks were present in all spectra, such as the peaks that arise at 725 or $738 \mathrm{~cm}^{-1}$ and it was noted that most of the groups had an absorbance peak at $830 \mathrm{~cm}^{-1}$ except for groups 2 and 6, the absorbance peak was at $889 \mathrm{~cm}^{-1}$. Another noticeable absorbance peak at $950 \mathrm{~cm}^{-1}$ was present in six of the eight groups and absent in groups 2 and 6 . This could be explained that groups 2 and 6 might be of different species. We suggest that further biochemical investigation might be needed for confirmed identification.

FTIR spectroscopy studies to bacteria employ traditional windows such as Zinc selenide (ZnSe) in preparing the adhesive culture [31]. In this work, silicone widow have been used, with transmittance scale $97 \%$ - 103\% T. This high specification allows absorption of incident radiation energy to occur by the adhesive culture rather by window, and hence, an accurate measurement is obtained. Results were analyzed by comparing both the line shapes of the FTIR spectra of species in the first derivative (see Figures 1-7) and the corresponding values in wave numbers of absorbance peaks in the fingerprint regions (see Table 2 and Table 3). Scans were performed in the mid IR range i.e. $4000-500 \mathrm{~cm}^{-1}$, although the range of concern is $1000-500 \mathrm{~cm}^{-1}$, in which the fingerprint region i.e. $900-700 \mathrm{~cm}^{-1}$ lies. This region needs studies since, some specific spectra patterns are not yet assigned to cellular components or functional groups [27]. In this study we look for minute differences between Enterococci isolates, other studies shown that they have high degree of similarity among [32].

Figure 1 shows the results of the arbitrary samples (AS), taken over a time span of nine days. The shift between spectra might be attributed to the difference in lab temperature at the different times of measurements; this effect is reported in many types of bacteria [33] [34] and needs further studies in Entricocci type. The nearly matching spectra indicate an almost equal concentration of the samples. Figure 2 shows a spectrum comparison of the standard strain ATCC $512299 \mathrm{VanB}$ and the isolated strain 44404 in the range $1000-500 \mathrm{~cm}^{-1}$. It indicates close line shape similarity of spectra but not quite identical especially in the fingerprint region. This is expected, since they both belong to the same genotype of VanB, but their site of collection is different. Table 2, shows for the previously mentioned samples, that their absorbance peaks in the range $1000-500 \mathrm{~cm}^{-1}$ is almost the same.

In Table 2 \& Table 3, absorption lines 738 or $724 \mathrm{~cm}^{-1}$ seems common among all samples in the fingerprint region. This observation indicates that Enterococci bacteria species have common organic compounds which identify its type. To confirm this conclusion, two different genera of bacteria other than enterococcus were measured by FTIR spectroscopy and the output absorbance peaks i.e. 738 or $724 \mathrm{~cm}^{-1}$ was absent in the fingerprint region (data not shown). Further studies have to be carried out with many genera of bacteria to establish a firm stands for this conclusion. The organic compound which is related to the absorbance peak value $724 \mathrm{~cm}^{-1}$ could be dimethylene, which has rocking vibration mode, and the value $829.66 \mathrm{~cm}^{-1}$ is related to the S-H band stretching vibration of the sulfite group [35]. The absorbance peak $950 \mathrm{~cm}^{-1}$ belongs to ammonia molecules at A1 symmetric, while the absorbance peak $610 \mathrm{~cm}^{-1}$ defines the sulfite ions again [35]. Therefore, FTIR was able to differentiate between VanA isolates and categorize them into 3 different groups, see Figure 3 and Table 2, in which the isolates 47120 \& 4898 were considered as group G2.

\section{Conclusion}

FTIR spectroscopy is a methodology that fingerprints the whole cell and is able to detect subtle compositional changes that cannot be revealed by conventional phenotypic or even genotypic methods. Contrary, antibiotic susceptibility testing was not discriminative enough when compared to FTIR. The later technique was used in this study to type Enterococcus clinical isolates and has proven very useful. It is easy to carry and allows the analysis of large number of strains, although it requires a high degree of standardization and complex data processing. In conclusion, certain physical and chemical properties do exist that can be determined by other means to study different molecules and organic compounds constituting part of the cell structure. This observation indicates that Enterococci bacteria species have organic compounds which can be used to identify its type and it is believed that FTIR has great potential in such clinical microbiology application.

\section{References}

[1] Bodnar, U.R., Noskin, G.A., Suriano, T., Cooper, I., Reisberg, B.E. Peterson, L.R. (1996) Journal of Clinical Microbiology, 34, 2129-2132. 
[2] Buschelman, B.J., Bale, M.J. and Jones, R.N. (1993) Diagnostic Microbiology and Infectious Disease, 16, $119-122$. http://dx.doi.org/10.1016/0732-8893(93)90005-R

[3] Cetinkaya, Y., Falk, P. and Mayhall, C.G. (2000) Clinical Microbiology Reviews, 13, 686-707.

[4] Cheng, S., McCleskey, F.K., Gress, M.J., Petroziello, J.M., Liu, R., Namdari, H., Beninga, K., Salmen, A. and DelVecchio, V.G. (1997) Journal of Clinical Microbiology, 35, 1248-1250.

[5] Clark, N.C., Weigel, L.M., Patel, J.B. and Tenover, F.C. (2005) Antimicrobial Agents and Chemotherapy, 49, $470-472$. http://dx.doi.org/10.1128/AAC.49.1.470-472.2005

[6] Devriese, L.A., Pot, B., Van Damme, L., Kersters, K. and Haesebrouck, F. (1995) International Journal of Food Microbiology, 26, 187-197. http://dx.doi.org/10.1016/0168-1605(94)00119-Q

[7] Dziuba, B., Babuchowski, A., Niklewicz, M. and Brzozowski, B. (2006) Milchwissenschaft, 61, 146-149.

[8] Goulden, J.D.S. and Sharpe, M.E. (1958) Microbiology, 19, 76-86. http://dx.doi.org/10.1099/00221287-19-1-76

[9] Greensteet, J.E.S. and Norris, K.P. (1957) Spectrochimica Acta, 9, 177-182. http://dx.doi.org/10.1016/0371-1951(57)80131-3

[10] Helm, D., Labischinski, H. and Naumann D. (1991) Journal of Microbiological Methods, 14, 127-142. http://dx.doi.org/10.1016/0167-7012(91)90042-O

[11] Jackson, M. and Mantsch, H. (1996) Biomedical Infrared Spectroscopy. In: Mantsch, H.H. and Chapman, D., Eds., Infrared Spectroscopy of Biomolecules, Wiley-Liss, New York.

[12] Jones, R.N., Marshall, S.A., Pfaller, M.A., Wilke, W.W., Hollis, R.J., Erwin, M.E., Edmond, M.B. and Wenzel, R.P. (1997) Diagnostic Microbiology and Infectious Disease, 29, 95-102. http://dx.doi.org/10.1016/S0732-8893(97)00115-6

[13] Ke, D., Picard, F.J., Martineau, F., Menard, C., Roy, P.H., Ouellette, M. and Bergeron, M.G. (1999) Journal of Clinical Microbiology, 37, 3497-3503.

[14] Kümmerle, M., Scherer, S. and Seiler, H. (1998) Applied and Environmental Microbiology, 64, 2207-2214.

[15] Maquelin, K., Kirschner, C., Choo-Smith, L.P., Ngo-Thi, N.A., van Vreeswijk, T., Stammler, M., Endtz, H.P., Bruining, H.A., Naumann, D. and Puppels, G.J. (2003) Journal of Clinical Microbiology, 41, 324-329. http://dx.doi.org/10.1128/JCM.41.1.324-329.2003

[16] Margarita, P. and Quinteiro, R. (2000) Clinical Microbiology Newsletter, 22, 57-61. http://dx.doi.org/10.1016/S0196-4399(00)88850-9

[17] Massai, R., Bantar, C., Lopardo, H., Vay, C. and Gutkind, G. (2007) Revista Argentina de Microbiología, 39, $199-203$.

[18] Monstein, H.J., Quednau, M., Samuelsson, A., Ahrne, S., Isaksson, B. and Jonasson, J. (1998) Microbiology, 144, 1171-1179. http://dx.doi.org/10.1099/00221287-144-5-1171

[19] Nakamoto, K. (1970) Infrared Spectra of Inorganic and Coordination Compounds. John Wiley, New York, 98.

[20] Naumann, D. (1998) Infrared and NIR Raman Spectroscopy in Medical Microbiology. In: Manch, H.H. and Jackson, M., Eds., Infrared Spectroscopy: New Tool in Medicine, SPIE, Bellingham, 245-257.

[21] Naumann, D., Helm, D. and Labischinski, H. (1991) Nature, 35, 81-82. http://dx.doi.org/10.1038/351081a0

[22] Naumann, D., Labischinski, H. and Giesbrecht, P. (1991) The Characterization of Microorganisms by Fourier-Transform Infrared Spectroscopy (FT-IR). In: Nelson, W.H., Ed., Modern Techniques for Rapid Microbiological Analysis, VCH, New York, 43-96.

[23] Abu-Teir, M., Abu-Taha, M.I., Al-Jamal, A. and Eideh, H.K. (2008) Journal of Applied Biological Sciences, 2, 113119.

[24] National Committee for Clinical Laboratory Standards, NCCLS (1999) Performance Standards for Antimicrobial Disk and Dilution Susceptibility Tests for Bacteria Isolated from Animals. Approved Standard M31-A., Wayne, 25.

[25] Oberreuter, H., Seiler, H. and Scherer, S. (2002) International Journal of Systematic and Evolutionary Microbiology, 52, 91-100.

[26] Quintiliani Jr., R., Evers, S. and Courvalin, P. (1994) FEMS Microbiology Letters, 119, 359-364. http://dx.doi.org/10.1111/j.1574-6968.1994.tb06913.x

[27] Ralph, H.P. (1982) General Chemistry. Principals and Modern Applications. Prentice Hall, Upper Saddle River, 215218.

[28] Riddle, J.W., Kabler, P.W., Kenner, B.A., Bordner, R.H., Rookwood, S.W. and Stevenson, H.J.R. (1956) Journal of Bacteriology, 72, 593-603.

[29] Roger, M., Faucher, M.C., Forest, P., St-Antoine, P. and Coutlee, F. (1999) Journal of Clinical Microbiology, 37, 3348-3349. 
[30] Schaberg, D.R., Culver, D.H. and Gaynes, R.P. (1991) The American Journal of Medicine, 91, 72S-75S. http://dx.doi.org/10.1016/0002-9343(91)90346-Y

[31] Schuster, K.C., Mertens, F. and Gapes, J.R. (1999) Vibrational Spectroscopy, 19, 467-477. http://dx.doi.org/10.1016/S0924-2031(98)00058-7

[32] Vincent, S., Knight, R.G., Green, M., Sahm, D.F. and Shlaes, D.M. (1991) Journal of Clinical Microbiology, 29, 23352337.

[33] Cherepy, N.J., Shreve, A.P., Moore, L.J., Boxer, S.G. and Mathies, R.A. (1997) Biochemistry, 36, 8559-8566. http://dx.doi.org/10.1021/bi970024r

[34] Alvarez-Ordóñez, A. and Prieto, M. (2010) Applied and Environmental Microbiology, 76, 7598-7607.

[35] Yang, J.L., Wang, M.S., Cheng, A.N., Pan, K.C., Li, C.F. and Deng, S.X. (2008) World Journal of Gastroenterology, 14, 2872-2876. http://dx.doi.org/10.3748/wjg.14.2872 
Scientific Research Publishing (SCIRP) is one of the largest Open Access journal publishers. It is currently publishing more than 200 open access, online, peer-reviewed journals covering a wide range of academic disciplines. SCIRP serves the worldwide academic communities and contributes to the progress and application of science with its publication.

Other selected journals from SCIRP are listed as below. Submit your manuscript to us via either submit@scirp.org or Online Submission Portal.
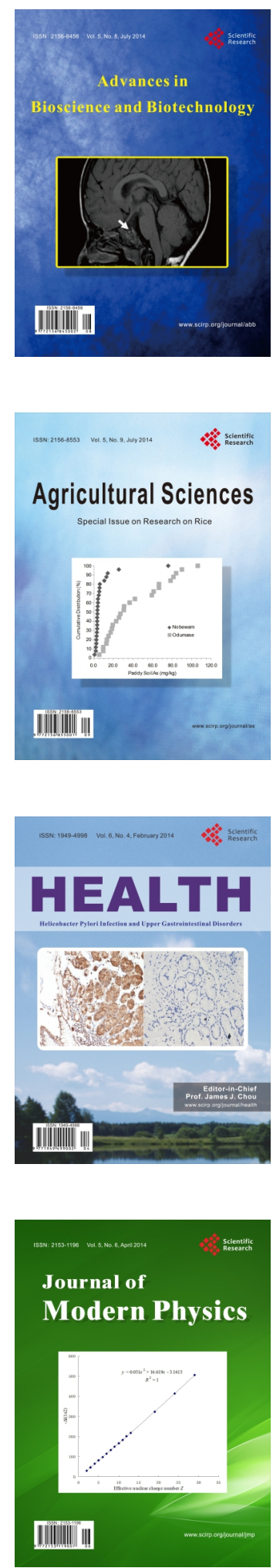
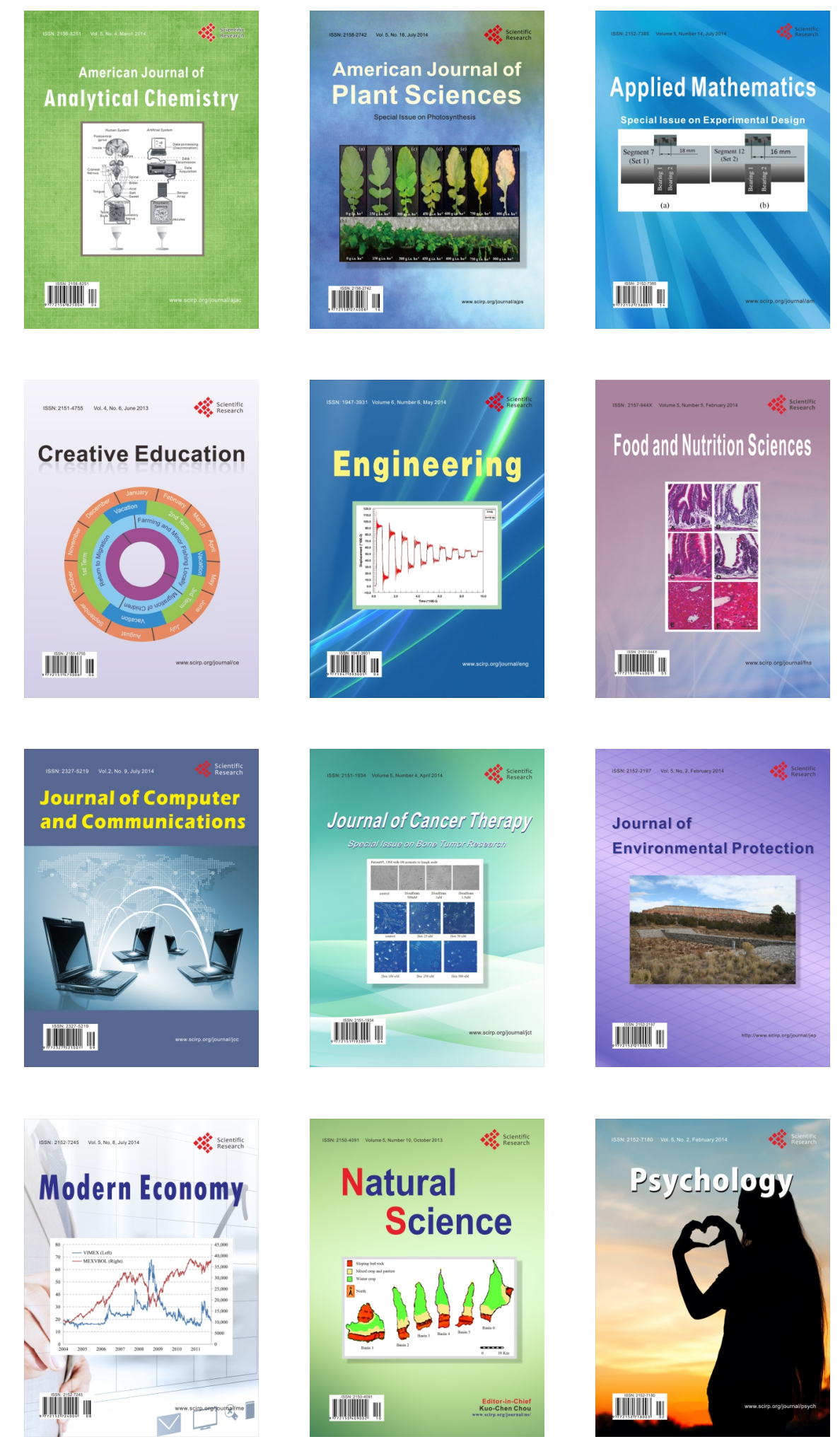